\title{
SOME NEW SPECIES OF TEXAS TACHINIDAE (DIPTERA)
}

\author{
By H. J. Reinhard, \\ Entomologist, Texas Experiment Station, College Station, Texas.
}

This paper includes the descriptions of six new species of Tachinidæ. Most of these were collected in the vicinity of College Station. The accompanying drawings were prepared by the writer to supplement the descriptions and assist in the recognition of the proposed new species. All type specimens are for the time being retained in the writer's collection. Grateful acknowledgment is here made to Dr. Herbert Osborn for helpful suggestions and to W. R. Walton for supplying important references.

\section{Ernestia frioensis n. sp.}

Male.-General color gray. Eyes distinctly hairy. Head slightly broader than thorax, diameter at the vibrissæ nearly as long as at base of antennæ. Front at narrowest point as wide as either eye. Frontal bristles in two rows, descending to the base of third antennal joint; the three posterior bristles in each row robust, and directed posteriorly. Genæ, facial depression and sides of face gray pollinose. The pollen on sides of the front, ocellar triangle, and upper portion of the posterior orbits tinged lightly with yellow. Frontal vitta entire, rather broad, opaque, black. Ocellar bristles robust, directed obliquely forward. Numerous long bristly hairs on ocellar triangle, and on front between the eyes and frontal rows, and extending downward below the lowest frontals to almost the middle of the face. Antennæ nearly as long as the face, first two joints yellow, third joint black, the latter nearly four times as long as second joint. Arista slender, a little longer than third antennal joint, microscopically pubescent, thickened on basal half, penultimate joint not longer than broad. Facial depression rather deep, distinctly carinate; ridges diverging but little below, bristly on lowest one-fourth. Sides of face on lower half bare, at narrowest point one-half as wide as the facial depression.* Vibrissæ inserted on a level with front border of oral margin. Proboscis short and fleshy; labella large. Palpi rather long, but little thickened distally, yellow. Cheeks covered on lower two-thirds with bristly hairs, one-half as broad as

* According to Coquillett's key-Rev. of Tach. p. 36, the genus Ernestia (Panzeria) is characterized by having the sides of the face at the narrowest part, less than one-third as wide as the median depression. A series of specimens of Ernestia radicum Fabr. from Ohio, New Mexico, and Kansas, all show the width of face one-third or more, as wide as the facial depression. 
eye-height. Thorax gray pollinose marked with five black vittæ, the median one narrow in front of suture. Four postsutural and three sternopleural macrochaetæ. Scutellum pollinose like thorax, yellow at apex, bearing three pairs of long marginal macrochaetæ and a shorter cruciate apical pair. Abdomen conical, gray pollinose on last three segments, with dark reflecting spots on dorsum, sides of second segment faintly yellow. First segment black, with a pair of weak dorsal and lateral marginal bristles. These bristles on the second segment are more robust, and it also bears a pair of discals. Third segment with a pair of discals and a marginal row, the fourth with a row of both discals and marginals. Wings hyaline, veins yellowish. First posterior cell open, terminating far before extreme wing tip. Third vein with two to four bristles at base. Fourth vein arcuate beyond bend, not appendiculate. Calypteres white. Legs black, knees yellowish. Middle tibia with a single stout bristle on front side near the middle, hind tibia subciliate. Front pulvilli nearly as long as last two tarsal joints.

Habitat.-Frio County, Texas. Described from two male specimens collected by the author May 4, 1920, from the blossoms of Acacia berlandieri, Benth.

In general appearance this fly is not so robust and more densely pollinose than E. radicum Fabr. It is separable from that species by the narrower and much longer third antennal segment. The front tarsi of the female is not dilated, and the last abdominal segment is black. It differs from Coquillett's penitalis by having yellow palpi, three pairs of long marginal scutellar macrochaetæ and four postsuturals.

\section{Pseudochaeta antennalis $\mathrm{n}$. sp.}

Length $7 \mathrm{~mm}$. Eyes sparsely hairy. Genæ, facial depression, sides of face, front, and posterior orbits silvery white pollinose. Front at vertex as wide as either eye, vitta entire, narrow, widening slightly at the base of antennæ, opaque, velvety-black. Two pairs of orbital bristles, ocellars absent, one posteriorly directed bristle on each side of front outside of frontal row, situated about midway between the lower ocellus and the posterior pair of orbital bristles; post ocellars well developed. Frontals in two rows, descending to base of third antennal segment; front, including ocellar triangle, with many long erect hairs. Antennæ five-sixths as long as face, third joint twice the length of second, black, except first joint, apex of second and base of third, which are yellowish. Arista long, slender, thickened on basal half, penultimate joint as broad as long. Facial depression large and rather flat; ridges strongly diverging downward, bristly on lowest one-fifth. Sides of face narrow and bare. Cheeks slightly over one-fifth the eyeheight, with a row of robust macrochaetæ along oral margin, and numerous long hairs. Vibrissæ inserted on a level with the front edge of the oral margin. Proboscis short and fleshy, labella large. Palpi yellow. Thorax with five black vittæ on the dorsum, gray pollinose. 
Four postsutural and four sternopleural macrochaetæ. Scutellum concolorous with thorax, bearing four pairs of long marginal macrochaetæ, the posterior pair reaching base of the third abdominal segment, also a shorter apical and discal pair, directed almost horizontally backward, the former is cruciate. Abdomen gray pollinose on bases of last three segments, narrow apical borders shining black, first segment black, subshining, with no macrochaetæ, sides of segments two and three faintly yellow, second with a pair of dorsal and lateral marginal macrochaetæ, third with a marginal row, fourth with an irregular row of discals and a row of marginals. Wings hyaline. Third vein with a single bristle at the base. First posterior cell widely open, terminating far before wing tip. Bend of fourth vein decidedly angulated, forming a right angle for some distance before it bends posteriorly, destitute of an appendage. Calypteres white. Legs black, middle tibia with three bristles on front side near the middle, hind tibia evenly ciliate outwardly.

Habitat.-College Station, Texas. Described from two female specimens collected by the author October 6, 1917, and September 18, 1920.

This fly is very closely allied to Coquillett's species pyralidis but differs from the description of that form as follows: Third antennal joint twice the length of second; facial ridges bristly on lowest one-fifth. Scutellum with four pairs of long marginal macrochaetæ. Cheeks equal one-fifth the eye-height. The four sternopleural macrochaetæ will serve to separate it from $P$. argentifrons Coq.

\section{Exorista loxostegeæ n. sp.}

Length 4.5 to $6 \mathrm{~mm}$., rather compact, black, thorax and abdomen gray pollinose, sub-shining.

Female.-Head slightly wider than thorax. Front at vertex as wide as either eye; sides cinereous pollinose, vitta one-third width of front, black, opaque; two pairs of orbital bristles, ocellars present, directed obliquely forward; frontal bristles in two rows, descending slightly below base of arista. Antennæ almost as long as face, second joint fuscous, one-fifth the length of third joint, the latter black, covered lightly with gray pubescence; arista microscopically pubescent, thickened on basal half, penultimate joint as broad as long. Facial depression, sides of face, and cheeks cinereous pollinose on a fuscous ground. Facial ridges bristly on little less than lower half; vibrissæ situated on level with front border of oral margin. Palpi black, sometimes yellowish at tips, proboscis short, fleshy, labella large, yellow. Eyes distinctly hairy. Dorsum of thorax with five black vittæ, the inner pair ending midway between the suture and base of scutellum, the median vitta linear in front of suture, almost as wide as outer pair post-suturally. Four postsuturals. Sternopleural macrochaetæ variable, usually four, sometimes with five or six on either side. Scutellum black, sometimes faintly yellow on apex, three pairs of marginal macrochaetæ, an apical 
pair directed almost vertically, and a pair of discals directed posteriorly. Abdomen short, ovate, first segment black, sub-shining, second segment sometimes with brown spot on sides. All segments except the first with discal macrochaetæ, pollinose at base, and dark reflecting spots on the dorsum. Wings hyaline, faintly yellow at base, all veins yellowish. Third vein with one to three bristles at the base. First posterior cell open, ending well before wing tip. Legs black, middle tibia bearing a single stout macrochaeta on the front side near the middle. Hind tibia ciliate.

Male.-Similar to female, differing as follows: Front slightly narrower, no orbital bristles, facial ridges usually bristly on at least the lower half, third joint of antennæ seven times length of second. Front pulvilli as long as last tarsal joint.

Habitat.-College Station, Texas. Described from 10 female and 14 male specimens, reared from Loxostege similalis Gn., by the author, June, 1920.

This species is readily referable to the genus Exorista. According to Coquillett's table-Revis. Tachinid, p. 92-it runs out under caption 2, where no provision is made for forms with four or more macochaetæ. In general appearance it somewhat resembles futilis O. S., but differs essentially from this and its other congeners by the presence of discal macrochaetæ and four sternopleurals.

\section{Houghia baccharis n. sp.}

Female-Black, gray pollinose. Front at vertex one and onefourth times as wide as either eye, white pollinose, frontal bristles in two rows, descending to the base of the third antennal joint, two pairs of orbital bristles, vertical and ocellar bristles robust, the latter directed obliquely forward. Frontal vitta rather narrow, opaque, dark-brown, extending from base of antennæ to ocelli where it is divided and extends on either side to the vertex. Facial depression shallow and large, not carinate, white pollinose. Antennæ as long as face, first two joints and base of third yellow, third joint nearly four times as long as second; arista black, microscopically pubescent, thickened on basal half, penultimate joint twice as long as wide. Sides of the face bare, narrow, concolorous with facial depression; facial ridges diverging below, with a few bristles above the vibrissæ. The latter on a level with oral margin, the front border of which is projecting; proboscis ridged, shining, black, labella fleshy, yellow; palpi normal, yellow, with only a few short bristles. Cheeks white pollinose, with short bristles and stout macrochaetæ, along oral margin; width about one-fifth the eye-height. Eyes bare. Thorax gray pollinose, marked with four narrow black vittæ on dorsal surface, the outer pair widening in front of suture. Four postsutural and four sternopleural macrochaetæ. Scutellum black, yellow at the apex, gray pollinose except along the base; three pairs of robust marginal macrochaetæ and a smaller apical pair; dorsal 
surface covered with short erect spines; abdomen somewhat conical, convex on dorsal surface, first segment black, sides yellowish, second and third white pollinose on basal half, shining apically, sides tinged with bronze; second segment with a pair of dorsal and lateral marginal bristles, third with a row of marginals; fourth segment white pollinose on base, on apical half shining reddish-yellow, a row of discal macrochaetæ and thickly covered with short spines on the apex. Wings hyaline, slightly yellowish at base, first vein with stout bristles near the base, bare on the apical three-fourths, second vein bristly nearly to small crossvein. First posterior cell widely open, terminating before the extreme wing tip. Calypteres white. Legs black, bristly, hind tibia not ciliate, middle tibia with three or four bristles on the front side near the middle. Length $7 \mathrm{~mm}$.

Habitat.-College Station, Texas. Described from a single female specimen collected by the author July 7, 1919, on the blossoms of Baccharis halimifolia L.

This species agrees well with Coquillett's description of $H$. setipennis. It differs from that species, which is the genotype, as follows: Proboscis more elongate and slender; last abdominal segment rufous; four sternopleural macrochaetæ; and the middle tibia with three or four macrochaetæ on the front side near the middle.

\section{Blepharipeza pollinosa n. sp.}

Length $6 \mathrm{~mm}$. Black, gray pollinose. Head wider than thorax.

Female.-Eyes with minute sparse hairs. Sides of front, upper portion of posterior orbits, and ocellar triangle golden pollinose. Front at vertex one and one-fourth times as wide as either eye, vitta about one-third width of front, opaque, reddish-brown. Two pairs of orbital bristles, ocellars directed obliquely forward. Frontal bristles in two rows extending from the vertex to base of third antennal segment, several stout bristles and more numerous shorter erect hairs between frontal row and eye. Antennæ five-sixths the length of face, third joint four times as long as second, black, second yellow at apex, first fuscous. Arista moderately long, microscopically pubescent, thickened on basal three-fourths, penultimate joint not longer than wide. Facial depression, cheeks, and sides of face fuscous, white pollinose; the latter with a few short bristles in the middle, at narrowest point less than one-third the width of facial depression; ridges strongly diverging below with three or four bristles above vibrissæ, which are inserted on a level with the oral margin. Proboscis fleshy, short, labella large, yellowish; palpi normal, yellow. Cheeks moderately bristly, one-fifth as wide as the eye-height. Thorax gray pollinose, with four black vittæ on dorsum, the outer pair interrupted at the suture forming a triangular spot in front. Three postsutural and three sternopleural macrochaetæ. Scutellum black, gray pollinose, with three pairs of long marginal, and a shorter cruciate apical pair of macrochaetæ. Abdomen short, ovate, 
all except first segment entirely gray pollinose, with dark reflecting spots on dorsum; thickly covered with suberect spines. First and second segments with a pair of dorsal and lateral marginal macrochaetæ, third with a marginal row, fourth segment covered with irregular rows of macrochaetæ. Wings hyaline. Costal spine minute. Third vein with two bristles at base. First posterior cell narrowly open, ending shortly before wing tip. Fourth vein beyond bend nearly straight, without a stump or fold. Hind crossvein nearly straight, the posterior end at less than one-third the distance from bend to small crossvein. Calypteres white, bordered with faint yellow. Legs black, hind tibia evenly ciliate outwardly, middle tibia with a single stout macrochaeta on the front side near the middle.

Male.-Differs from female as follows: Front narrower, at vertex as wide as either eye, no orbital bristles, front pulvilli as long as the tarsal joint, hind crossvein S shaped and posterior end at one-third the distance from bend to small crossvein.

Habitat.-College Station, Texas. Described from one female specimen (the type), collected May 25, 1920, and one male specimen collected June 12, 1919, by the author.

This species runs to Blepharipeza, according to Coquillett's key-Revis. Tachinid, p. 35. Superficially it is strikingly unlike any species of this genus which the writer has seen. It is smaller, more densely pollinose, and the bristles of the scutellum and abdomen are weaker and less numerous. In the absence of sufficient comparative material it seems desirable to provisionally place the species in Blepharipeza, until reliable characters are obtained which will justify the erection of a new genus for the reception of this species.

Chaetoplagia modesta n. sp.

Female.-Black, silvery pollinose, head obtusely conical. Front at vertex one and one-half times as wide as either eye, white pollinose, two rows of frontal bristles extending almost to base of third antennal segment, directed inward and converging towards base of antennæ; an irregular row of weaker bristles and numerous hairs between the frontal row and eye. Two pairs orbital bristles present; ocellar bristles diverging strongly and directed forward. Facial depression narrow and deep, ridges nearly parallel, with three or four bristles at base above vibrissæ. Antennæ nearly as long as face, black except second joint, which is brownish-yellow, length of third joint about seven times the second; arista short, bare, black, thickened on basal two-thirds, penultimate joint slightly longer than wide. Sides of face silvery white pollinose, with a row of ventrally directed macrochaetæ on each side. The facial bristles begin as short hairs on a level with insertion of the arista, and become more robust and longer towards the lower corner of the eye; numerous short hairs between the facial row and the eye. 
Vibrissæ cruciate, situated on level with oral margin; proboscis moderately long, palpi black. Cheeks white pollinose, covered with black hairs, width about one-seventh the eye-height. Eyes bare. Thorax black, white pollinose, marked with four black vittæ. Three postsutural and two sternopleural macrochaetæ. Scutellum black, white pollinose on apical half, with three pairs of long marginal macrochaetæ. Abdomen ovate, first segment shining black, segments two, three, and four white pollinose on basal three-fourths, distal portions of each shining black. First segment destitute of dorsal or lateral marginal macrochaetæ, fourth with a marginal row of five, no discal macrochaetæ. Wings hyaline, veins yellow, costal spine minute, first vein bristly except at the base and apex, second vein bristly nearly to the small crossvein. First posterior cell open, terminating far before the extreme wing tip. Bend of fourth vein distinctly angulated, bearing a long appendage. Posterior end of hind crossvein nearer bend of the fourth than to small crossvein. Calypteres white, legs black, moderately bristly, hind tibia outwardly ciliate, middle tibia with one bristle on the front side near the middle. Length $7 \mathrm{~mm}$.

Habitat.-College Station, Texas. Described from a single female specimen collected by the author July 19, 1918.

This little fly differs markedly from Coquillett's genotype atripennis, which heretofore has been the only representative of this genus reported from our fauna. Coquillett's form is black, almost destitute of pollen, and sub-shining, with clouded or smoky wings. This species is smaller and covered with silvery white pollen. The wings are hyaline. It differs from Tothill's asiatica, described from India, Bull. Ent. Resch. Vol. IX, part 1, May, 1918 - by the short second aristal segment; two sternopleural macrochaetæ; black palpi; and the bristles on the third longitudinal vein extending hardly to the small crossvein.

\section{EXPLANATION OF PLATE XXVIII.}

Fig. 1. Lateral view of head of Ernestia frioensis.

Fig. 2. Right wing of Ernestia frioensis.

Fig. 3. Lateral view of head of Pseudochaeta antennalis.

Fig. 4. Right wing of Pseudochaeta antennalis.

Fig. 5. Lateral view of head of Houghia baccharis.

Fig. 6. Right wing of Houghia baccharis.

Fig. 7. Lateral view of head of Blepharipeza pollinosa.

Fig. 8. Right wing of Blepharipeza pollinosa.

Fig. 9. Lateral view of head of Chaetoplagia modesta.

Fig. 10. Right wing of Chaetoplagia modesta. 


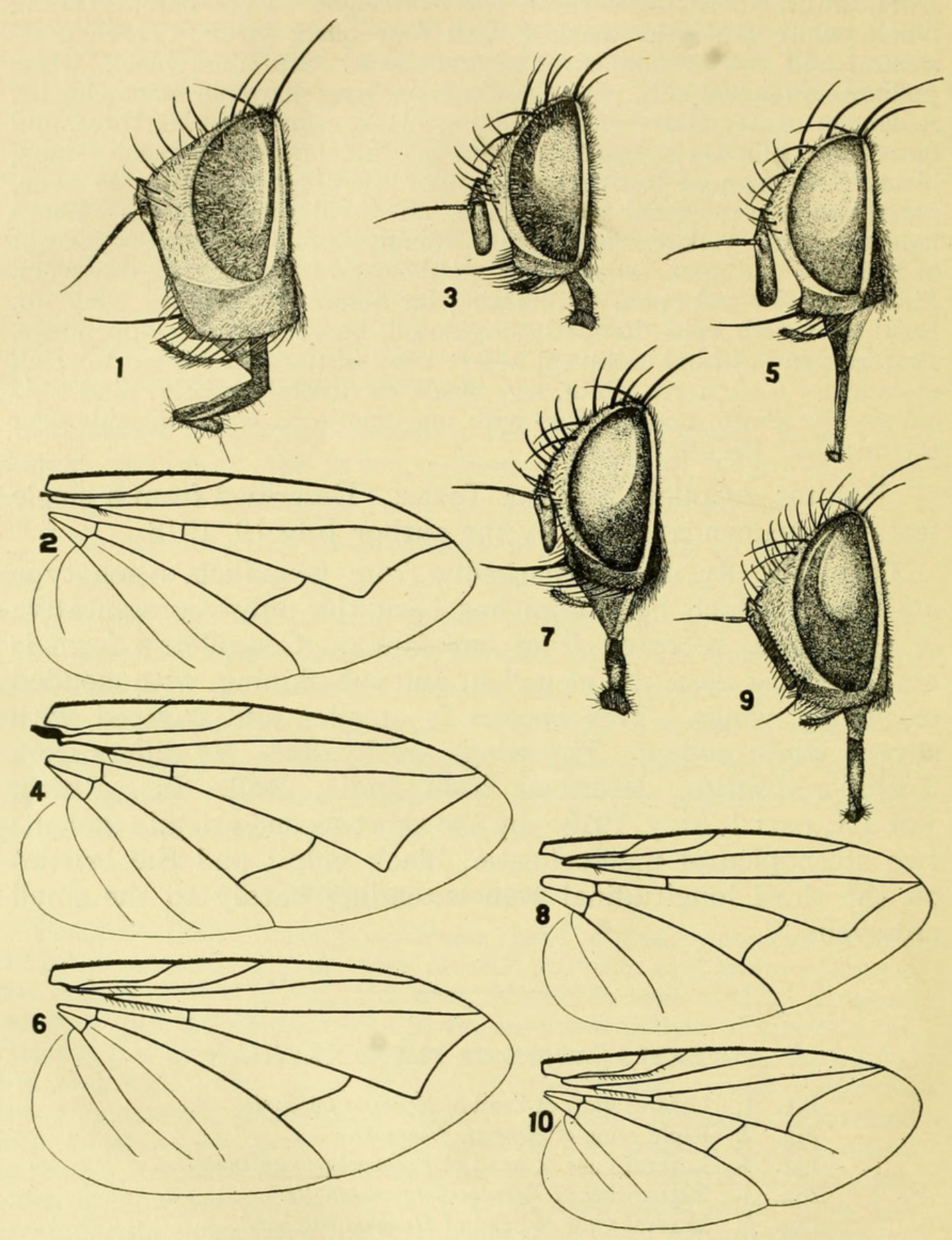

H. J. Reinhard. 


\section{$2 \mathrm{BHL}$ Biodiversity Heritage Library}

Reinhard, H J. 1922. "Some new species of Texas Tachinidae (Diptera)." Annals of the Entomological Society of America 14, 329-336.

https://doi.org/10.1093/aesa/14.4.329.

View This Item Online: https://www.biodiversitylibrary.org/item/43628

DOI: https://doi.org/10.1093/aesa/14.4.329

Permalink: https://www.biodiversitylibrary.org/partpdf/29698

\section{Holding Institution}

Smithsonian Libraries

\section{Sponsored by}

Smithsonian

\section{Copyright \& Reuse}

Copyright Status: NOT_IN_COPYRIGHT

This document was created from content at the Biodiversity Heritage Library, the world's largest open access digital library for biodiversity literature and archives. Visit BHL at https://www.biodiversitylibrary.org. 